\title{
Absorption spectra and cyclic voltammograms of uranium species in molten lithium molybdate-sodium molybdate eutectic at $550{ }^{\circ} \mathrm{C}$
}

\author{
By T. Nagai ${ }^{1, *}$, A. Uehara ${ }^{2}$, M. Fukushima ${ }^{1}$, M. Myochin ${ }^{1}$, T. Fujii ${ }^{2}$, N. Sato ${ }^{3}$ and H. Yamana ${ }^{2}$ \\ ${ }^{1}$ Nuclear Fuel Cycle Engineering Lab., Japan Atomic Energy Agency, 4-33, Muramatsu, Tokai, Naka, Ibaraki 319-1194, Japan \\ 2 Research Reactor Institute, Kyoto University, 2-1010, Asashiro Nishi, Kumatori, Sennan, Osaka 590-0494, Japan \\ ${ }^{3}$ Institute of Multidisciplinary Research for Advanced Materials, Tohoku University, 2-1-1, Katahira, Aoba, Sendai, Miyagi 980-8577, Japan
}

(Received December 27, 2009; accepted in revised form October 25, 2010)

Uranium / Absorption spectrum / Cyclic voltammogram / $\mathrm{Li}_{2} \mathrm{MoO}_{4}-\mathrm{Na}_{2} \mathrm{MoO}_{4}$ eutectic

Summary. Absorption spectra of uranium species dissolved in molten lithium molybdate-sodium molybdate eutectic of $0.51 \mathrm{Li}_{2} \mathrm{MoO}_{4}-0.49 \mathrm{Na}_{2} \mathrm{MoO}_{4}$ mixture at $550{ }^{\circ} \mathrm{C}$ were measured by UV/Vis/NIR spectrophotometry, and their redox reactions were investigated by cyclic voltammetry. We found that the major ions of uranium species dissolved in the melt were uranyl penta-valent. After purging dry oxygen gas into the melt, pentavalent species were oxidized to the uranyl hexa-valent. In the cyclic voltammetry of the melt without uranium species, it was confirmed that the lithium-sodium molybdenum oxide compounds were deposited on the working electrode at the negative potential and the lithium molybdenum oxide compounds were deposited on the counter electrode at positive potential. When $\mathrm{UO}_{2}$ was dissolved into the melt, the reductive reaction of the uranium species was observed at the reductive potential of the pure melt. This suggests that the uranium species dissolved in the melts could be recovered as mixed uranium-molybdenum oxides by electrolysis.

\section{Introduction}

The study of a pyrochemical process by using an alkaline molybdate melt has been carried out as a candidate reprocessing process for spent nuclear oxide fuels. This alkaline molybdate melt has a useful characteristic, which is an ability to dissolve uranium oxides, such as $\mathrm{UO}_{2}$ in a short time. In the previous study [1], the $\mathrm{UO}_{2}$ pellet was dissolved into molten sodium molybdate mixtures of $\mathrm{Na}_{2} \mathrm{MoO}_{4}-\mathrm{Na}_{2} \mathrm{Mo}_{2} \mathrm{O}_{7}$ at $750{ }^{\circ} \mathrm{C}$ in an alumina crucible and uranium species dissolved in the melts were recovered as $\mathrm{UO}_{2}$ particles by electrolysis at $700{ }^{\circ} \mathrm{C}$. It was confirmed by the X-ray photoelectron spectroscopy (XPS) analysis of the coagulation salt samples that the uranium species in molten $\mathrm{Na}_{2} \mathrm{MoO}_{4}-\mathrm{Na}_{2} \mathrm{Mo}_{2} \mathrm{O}_{7}$ mixtures after dissolving the $\mathrm{UO}_{2}$ pellet were tetra-valent ions. However, this dissolved uranium species in molten $\mathrm{Na}_{2} \mathrm{MoO}_{4}-\mathrm{Na}_{2} \mathrm{Mo}_{2} \mathrm{O}_{7}$ mixtures might be penta-valent ions since the $\mathrm{U} 4 f_{7 / 2}$ binding energy of uranium tetra-valent judged in the XPS analysis is close to the binding energy of a uranium penta-valent of a ura-

*Author for correspondence

(E-mail: nagai.takayuki00@jaea.go.jp.) nium molybdenum compound, $\mathrm{UMoO}_{5}$ [2]. Moreover, the coordination circumstances of uranium species in alkaline molybdate melts have not been studied because the melting point of $\mathrm{Na}_{2} \mathrm{MoO}_{4}$ is high and the spectrum measurement cell made of quartz is damaged by the salt after melting. So the absorption spectrum has never been reported.

In this study, absorption spectra of uranium species dissolved in molten lithium molybdate-sodium molybdate eutectic of $0.51 \mathrm{Li}_{2} \mathrm{MoO}_{4}-0.49 \mathrm{Na}_{2} \mathrm{MoO}_{4}$ mixture at $550{ }^{\circ} \mathrm{C}$ were measured by UV/Vis/NIR spectrophotometry, and their redox reactions were also investigated by cyclic voltammetry. The melting point of $\mathrm{Li}_{2} \mathrm{MoO}_{4}-\mathrm{Na}_{2} \mathrm{MoO}_{4}$ eutectic is lower than that of $\mathrm{Na}_{2} \mathrm{MoO}_{4}$ or $\mathrm{Na}_{2} \mathrm{MoO}_{4}-\mathrm{Na}_{2} \mathrm{Mo}_{2} \mathrm{O}_{7}$ mixtures [3], and the corrosion damage of the quartz cell can be avoided.

\section{Experimental}

\subsection{Reagents}

Anhydrous $\mathrm{Li}_{2} \mathrm{MoO}_{4}$ and $\mathrm{Na}_{2} \mathrm{MoO}_{4}$ of purity $99 \%$ up were purchased from Kojundo Chemical Lab. Co., Ltd. and processed by vacuum drying at $150{ }^{\circ} \mathrm{C}$ before use. To confirm the chemical composition of $\mathrm{Li}_{2} \mathrm{MoO}_{4}-\mathrm{Na}_{2} \mathrm{MoO}_{4}$ eutectic, the $\mathrm{Li}_{2} \mathrm{MoO}_{4}-\mathrm{Na}_{2} \mathrm{MoO}_{4}$ mixtures with mole ratio of $\left[\mathrm{Li}_{2} \mathrm{MoO}_{4}\right] /\left[\mathrm{Na}_{2} \mathrm{MoO}_{4}\right]$ from $[0.46] /[0.54]$ to $[0.54] /[0.46]$ were melted at $750{ }^{\circ} \mathrm{C}$ and melting points of these coagulation salts were measured by the thermal analysis. The simultaneous thermogravimetric and differential thermal analysis instrument, DTG-50H of Shimadzu Co., Ltd. in dry argon atmosphere was used for this thermal analysis. The eutectic composition was $0.51 \mathrm{Li}_{2} \mathrm{MoO}_{4}-0.49 \mathrm{Na}_{2} \mathrm{MoO}_{4}$ as shown in Fig. 1 as a result of the thermal analysis, and it agreed with the reference [3]. The $\mathrm{Li}_{2} \mathrm{MoO}_{4}-\mathrm{Na}_{2} \mathrm{MoO}_{4}$ eutectic salt utilized in this measurement was prepared by melting the mixed anhydrous reagents of $\mathrm{Li}_{2} \mathrm{MoO}_{4}$ and $\mathrm{Na}_{2} \mathrm{MoO}_{4}$ with the above-mentioned eutectic composition.

The $\mathrm{UO}_{2}$ powder was loaded into molten $\mathrm{Li}_{2} \mathrm{MoO}_{4}$ $\mathrm{Na}_{2} \mathrm{MoO}_{4}$ eutectic at $550{ }^{\circ} \mathrm{C}$ in a quartz tube by adding $\mathrm{MoO}_{3}$ of twice mole amount of $\mathrm{UO}_{2}$, and argon gas was purged into the melt until the $\mathrm{UO}_{2}$ dissolution was completed. Then this source material containing uranium species was added into the measurement melts used in the absorption spectrophotometry and cyclic voltammetry. 


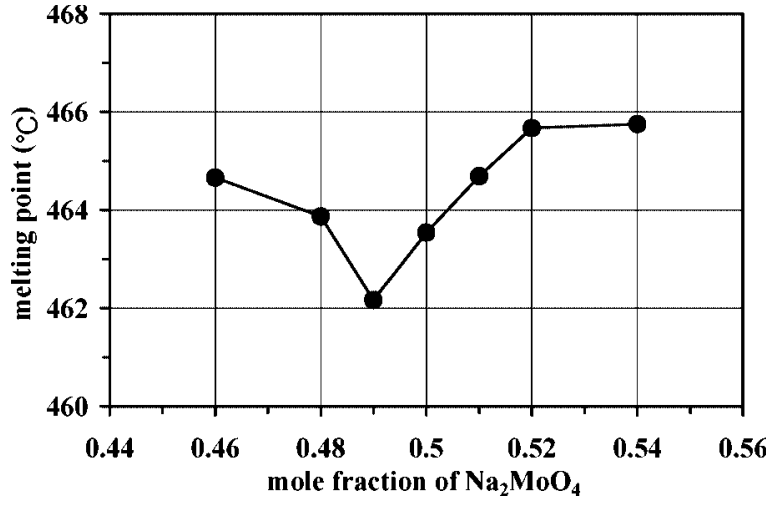

Fig. 1. Melting point of $\mathrm{Li}_{2} \mathrm{MoO}_{4}-\mathrm{Na}_{2} \mathrm{MoO}_{4}$ mixtures.

\subsection{Apparatus and procedure}

All the measurements were carried out in a glove box filled with dry argon where humidity and oxygen impurity were kept less than $1 \mathrm{ppm}$. The optical measurement system for the molten salt sample is described in detail elsewhere [4]. The sample temperature was kept at $550 \pm 1{ }^{\circ} \mathrm{C}$ by an automatically controlled electric furnace.

The absorption spectrophotometry was carried out by using the sample cell of a quartz tube, $350 \mathrm{~mm}$ in length and $13 \mathrm{~mm}$ in inner diameter. At the bottom of the tube an optical cell having a $10 \mathrm{~mm}$ light path was welded. About $10 \mathrm{~g}$ of the prepared $\mathrm{Li}_{2} \mathrm{MoO}_{4}-\mathrm{Na}_{2} \mathrm{MoO}_{4}$ eutectic salt was put into the sample cell and they were heated to $550^{\circ} \mathrm{C}$. After taking the background absorption spectrum of pure $\mathrm{Li}_{2} \mathrm{MoO}_{4}-\mathrm{Na}_{2} \mathrm{MoO}_{4}$ eutectic at $550^{\circ} \mathrm{C}$, a portion of the source material containing uranium species was added into the melt and the absorption spectrum of uranium species in the $\mathrm{Li}_{2} \mathrm{MoO}_{4}-\mathrm{Na}_{2} \mathrm{MoO}_{4}$ eutectic was measured. A self-registering spectrophotometer, V-350 of JASCO Co. was used for the absorption spectrophotometry over the wavenumber from 5000 to $25000 \mathrm{~cm}^{-1}$.

In the cyclic voltammetry, about $10 \mathrm{~g}$ of the $\mathrm{Li}_{2} \mathrm{MoO}_{4}-$ $\mathrm{Na}_{2} \mathrm{MoO}_{4}$ eutectic and the source material containing uranium species were put into the measurement cell made of quartz tube of $13 \mathrm{~mm}$ in inner diameter and heated to $550^{\circ} \mathrm{C}$. After melting was completed, three electrodes were all inserted into the measurement cell: a working, a counter and a reference electrode. Two platinum wires of $1 \mathrm{~mm}$ diameter were used as the working and counter electrodes, and these electrodes were inserted to a depth of $10 \mathrm{~mm}$ into melts for the measurements. The reference electrode utilized was composed of a PYREX tube with about $1 \mathrm{~g}$ of $12.17 \mathrm{~mol} \%$ $\mathrm{MoO}_{3}$ in $\mathrm{Li}_{2} \mathrm{MoO}_{4}-\mathrm{Na}_{2} \mathrm{MoO}_{4}$ eutectic and a platinum wire, referring to the electrode structure that Smolenskii et al. had reported [5]. An electrochemical measurement system, HAG-5001 of Hokuto Denko Co. was used for the cyclic voltammetry.

\section{Results and discussion}

\subsection{Absorption spectra of uranium species in molten $\mathrm{Li}_{2} \mathrm{MoO}_{4}-\mathrm{Na}_{2} \mathrm{MoO}_{4}$ eutectic}

Fig. 2 shows the absorption spectrum of $\mathrm{Li}_{2} \mathrm{MoO}_{4}-\mathrm{Na}_{2} \mathrm{MoO}_{4}$ eutectic at $550{ }^{\circ} \mathrm{C}$. This $\mathrm{Li}_{2} \mathrm{MoO}_{4}-\mathrm{Na}_{2} \mathrm{MoO}_{4}$ eutectic has

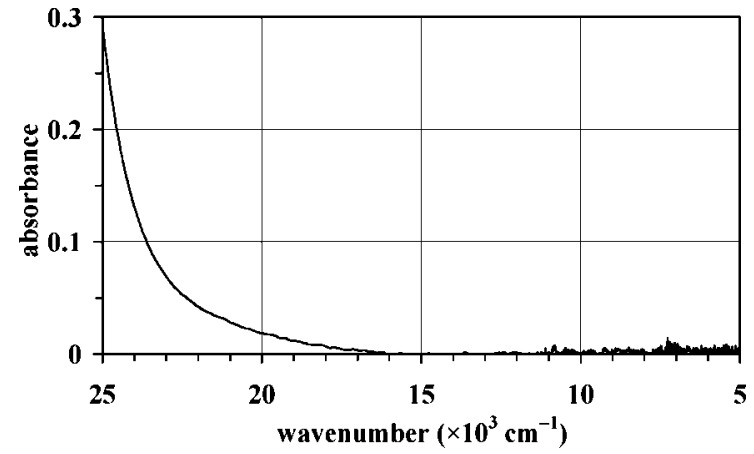

Fig. 2. An absorption spectrum of $\mathrm{Li}_{2} \mathrm{MoO}_{4}-\mathrm{Na}_{2} \mathrm{MoO}_{4}$ eutectic at $550{ }^{\circ} \mathrm{C}$.

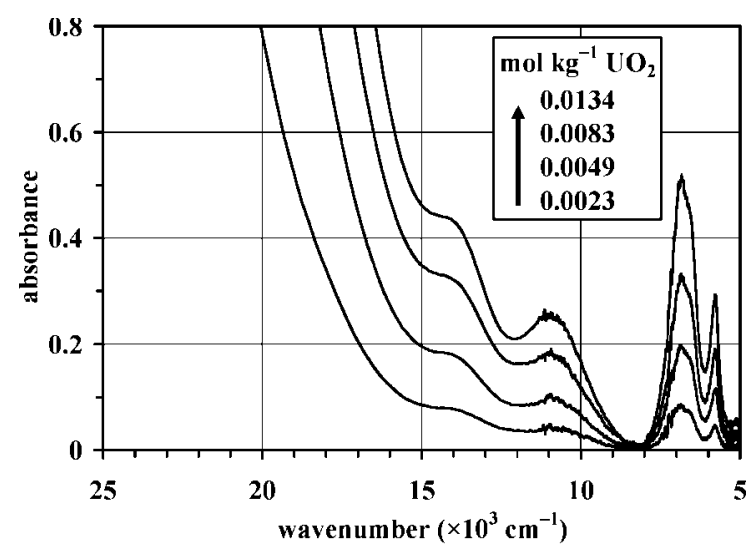

Fig. 3. Absorption spectra of uranium species in molten $\mathrm{Li}_{2} \mathrm{MoO}_{4}-$ $\mathrm{Na}_{2} \mathrm{MoO}_{4}$ eutectic at $550{ }^{\circ} \mathrm{C}$.

a broad absorption band over $17000 \mathrm{~cm}^{-1}$ in UV/Vis regions, and this absorption was similar to the case of a sodium molybdate solution [6].

Absorption spectra of uranium in molten $\mathrm{Li}_{2} \mathrm{MoO}_{4}$ $\mathrm{Na}_{2} \mathrm{MoO}_{4}$ eutectic at $550^{\circ} \mathrm{C}$ were observed as shown in Fig. 3. The absorption peaks were found at 14000, 11000 , 6700 , and $5700 \mathrm{~cm}^{-1}$ in Vis/NIR regions. The absorption profile was similar to that of uranyl penta-valent ion, $\mathrm{UO}_{2}{ }^{+}$, in molten chlorides [7], and corresponded to the $f-f$ electronic transitions that had been identified in molten $\mathrm{NaCl}-\mathrm{CsCl}$ [8]. A huge absorption band observed over $16000 \mathrm{~cm}^{-1}$ in UV/Vis regions was similar to that of $\mathrm{UO}_{2}^{+}$ in sodium silicate glass [9]. Therefore, the predominant uranium species in the molten $\mathrm{Li}_{2} \mathrm{MoO}_{4}-\mathrm{Na}_{2} \mathrm{MoO}_{4}$ eutectic is $\mathrm{UO}_{2}{ }^{+}$when $\mathrm{UO}_{2}$ is dissolved into the melt.

To confirm the stability of $\mathrm{UO}_{2}{ }^{+}$in molten $\mathrm{Li}_{2} \mathrm{MoO}_{4}{ }^{-}$ $\mathrm{Na}_{2} \mathrm{MoO}_{4}$ eutectic, dry oxygen gas was purged into the melt and absorption spectra were measured. After purging oxygen gas, the characterized absorption peaks of $\mathrm{UO}_{2}{ }^{+}$at $14000,11000,6700$, and $5700 \mathrm{~cm}^{-1}$ disappeared and a huge charge transfer absorption band appeared over $17000 \mathrm{~cm}^{-1}$ in UV/Vis regions, as shown in Fig. 4. In addition to this huge absorption band, a small absorption peak by the uranyltype electronic transition can be seen at $22500 \mathrm{~cm}^{-1}$, as a shoulder on the huge absorption. The absorption profile was similar to that of uranyl hexa-valent ion, $\mathrm{UO}_{2}{ }^{2+}$, in molten $\mathrm{LiCl}-\mathrm{KCl}[10,11], \mathrm{NaCl}-\mathrm{CsCl}$ [4] eutectics and sodium silicate glass [9]. This suggests that $\mathrm{UO}_{2}{ }^{+}$in the molten $\mathrm{Li}_{2} \mathrm{MoO}_{4}-\mathrm{Na}_{2} \mathrm{MoO}_{4}$ eutectic was oxidized to $\mathrm{UO}_{2}{ }^{2+}$ by oxygen in the melt. 


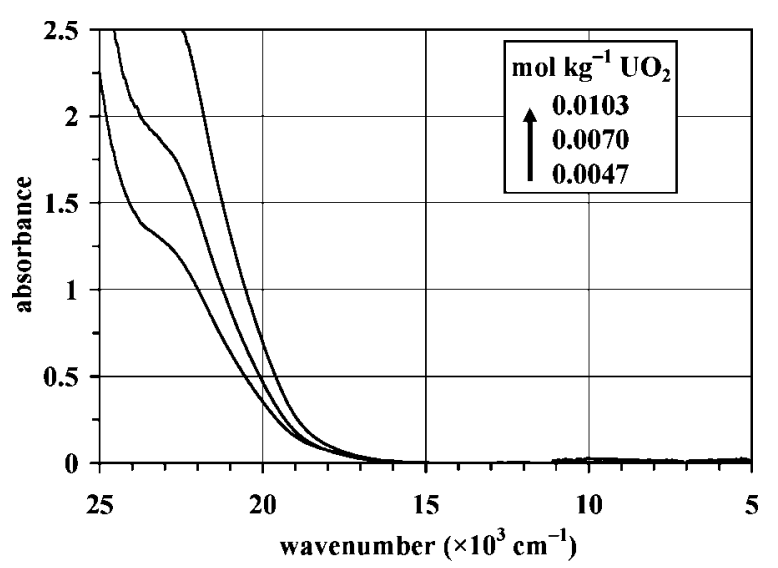

Fig. 4. Absorption spectra of uranium species in molten $\mathrm{Li}_{2} \mathrm{MoO}_{4}-$ $\mathrm{Na}_{2} \mathrm{MoO}_{4}$ eutectic at $550{ }^{\circ} \mathrm{C}$ after oxygen gas purging into the melt.

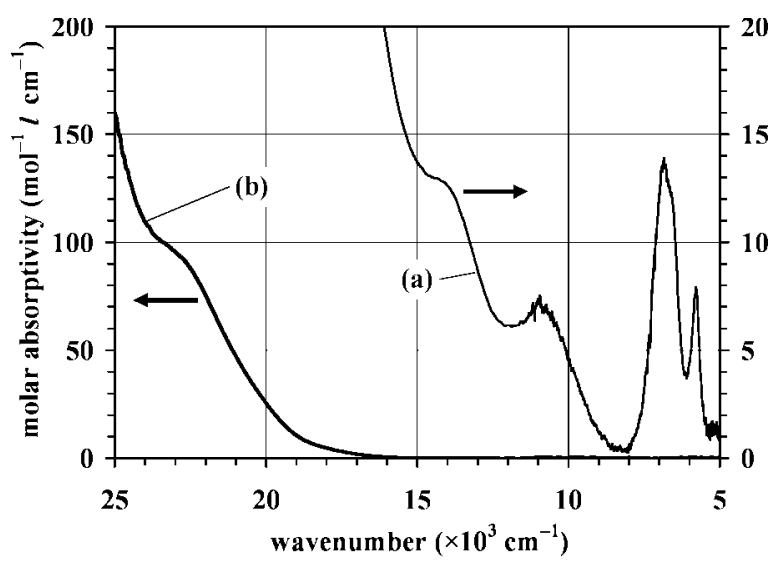

Fig. 5. Molar absorptivity of uranium species in molten $\mathrm{Li}_{2} \mathrm{MoO}_{4}-$ $\mathrm{Na}_{2} \mathrm{MoO}_{4}$ eutectic at $550{ }^{\circ} \mathrm{C}$, (a) before and (b) after oxygen gas purging.

Absorbance at several peaks shown in Figs. 3 and 4 was proportional to the concentration of uranium. Fig. 5 shows the molar absorptivities of uranium species in the melt before/after the purging dry oxygen gas that were calculated from the measured spectra in Figs. 3 and 4. The density of molten $\mathrm{Li}_{2} \mathrm{MoO}_{4}-\mathrm{Na}_{2} \mathrm{MoO}_{4}$ eutectic at $550{ }^{\circ} \mathrm{C}$ was approximated as $2.781 \mathrm{~g} \mathrm{~cm}^{-3}$ from the calculation by using the density of molten pure $\mathrm{Li}_{2} \mathrm{MoO}_{4}$ and $\mathrm{Na}_{2} \mathrm{MoO}_{4}$ [12], as shown in Eqs. (1) and (2).

$$
\begin{aligned}
& \rho_{\mathrm{Li}_{2} \mathrm{MoO}_{4}}\left(\mathrm{~g} \mathrm{~cm}^{-3}\right)=2.886-0.2380 \times 10^{-3} \mathrm{~T}\left({ }^{\circ} \mathrm{C}\right) \\
& \rho_{\mathrm{Na}_{2} \mathrm{MoO}_{4}}\left(\mathrm{~g} \mathrm{~cm}^{-3}\right)=3.168-0.6542 \times 10^{-3} \mathrm{~T}\left({ }^{\circ} \mathrm{C}\right)
\end{aligned}
$$

In our previous analysis of uranyl ions in molten $\mathrm{NaCl}-$ $\mathrm{CsCl}$ eutectic at $650^{\circ} \mathrm{C}$ [4], the molar absorptivities of $\mathrm{UO}_{2}{ }^{+}$ were determined to be $12.5 \mathrm{~mol}^{-1} \mathrm{lcm}^{-1}$ at $16100 \mathrm{~cm}^{-1}$ and $15.9 \mathrm{~mol}^{-1} \mathrm{lcm}^{-1}$ at $12900 \mathrm{~cm}^{-1}$, and that of $\mathrm{UO}_{2}{ }^{2+}$ $57.2 \mathrm{~mol}^{-1} 1 \mathrm{~cm}^{-1}$ at $22200 \mathrm{~cm}^{-1}$. The dissolved uranium species in molten $\mathrm{Li}_{2} \mathrm{MoO}_{4}-\mathrm{Na}_{2} \mathrm{MoO}_{4}$ eutectic after purging oxygen gas can be assigned to $\mathrm{UO}_{2}{ }^{2+}$, because there were no peaks corresponding to $\mathrm{UO}_{2}{ }^{+}$. The molar absorptivity of the shoulder peak at $22500 \mathrm{~cm}^{-1}$ of $\mathrm{UO}_{2}{ }^{2+}$ in molten $\mathrm{Li}_{2} \mathrm{MoO}_{4}-$ $\mathrm{Na}_{2} \mathrm{MoO}_{4}$ eutectic, as shown line (b) in Fig. $5(\varepsilon=88.3)$, was larger than those of $\mathrm{UO}_{2}{ }^{2+}$ in molten $\mathrm{NaCl}-\mathrm{CsCl}[4]$ and $\mathrm{LiCl}-\mathrm{KCl}$ eutectics $[10,11]$.

\subsection{Cyclic voltammograms of uranium species in molten $\mathrm{Li}_{2} \mathrm{MoO}_{4}-\mathrm{Na}_{2} \mathrm{MoO}_{4}$ eutectic}

Fig. 6 shows cyclic voltammograms in molten pure $\mathrm{Li}_{2} \mathrm{MoO}_{4}-\mathrm{Na}_{2} \mathrm{MoO}_{4}$ eutectic at $550^{\circ} \mathrm{C}$. The deposition of lithium-sodium molybdenum oxide compounds on the working electrode was observed below $-1.0 \mathrm{~V}$ (vs. reference electrode), as shown $1 \mathrm{c}$ in Fig. 6. The deposited compounds were analyzed by the X-ray diffraction (XRD) and they were various alkali molybdenum oxides such as the lithium molybdenum oxides and the lithium-sodium molybdenum oxides. The oxygen gas could have been generated from the working electrode surface over $0.8 \mathrm{~V}$ of 3a in Fig. 6, since the deposition of molybdate compounds was observed on the counter electrode and these compounds were identified by the XRD analysis to be lithium molybdenum oxides of $\mathrm{Li}_{2} \mathrm{MoO}_{3}$ and $\mathrm{Li}_{6} \mathrm{Mo}_{2} \mathrm{O}_{7}$. These are presumed to be generation with the reactions of Eqs. (3) and (4) corresponding to the oxygen gas generation Eq. (5).

$$
\begin{aligned}
& 2 \mathrm{Li}^{+}+\mathrm{MoO}_{3}+2 \mathrm{e}^{-} \rightarrow \mathrm{Li}_{2} \mathrm{MoO}_{3} \\
& 6 \mathrm{Li}^{+}+2 \mathrm{MoO}_{3}+\mathrm{O}^{2-}+4 \mathrm{e}^{-} \rightarrow \mathrm{Li}_{6} \mathrm{Mo}_{2} \mathrm{O}_{7} \\
& 2 \mathrm{O}^{2-} \rightarrow \mathrm{O}_{2}+4 \mathrm{e}^{-}
\end{aligned}
$$

The oxidizing reaction peak of 1a in Fig. 6 was a redissolution of deposited lithium-sodium molybdenum oxides on the working electrode, and the reductive reaction of $3 \mathrm{c}$ in Fig. 6 was thought to be re-dissolution of adhering oxygen bubbles on the working electrode. The reactions of $2 \mathrm{c}$ at $-0.5 \mathrm{~V}$ and $2 \mathrm{a}$ at $-0.3 \mathrm{~V}$ in Fig. 6 were deposition and dissolution of molybdate compounds, because the thin deposit was observed on the working electrode surface after the experiment.

From measured cyclic voltammograms as shown in Fig. 6, it was found that the potential width of electrochemical window in molten $\mathrm{Li}_{2} \mathrm{MoO}_{4}-\mathrm{Na}_{2} \mathrm{MoO}_{4}$ eutectic was about $1.8 \mathrm{~V}$ at $550{ }^{\circ} \mathrm{C}$. This potential width was narrower than that in the molten chlorides, since the deposition potential of lithium-sodium molybdenum oxides was more positive than that of the alkali metals.

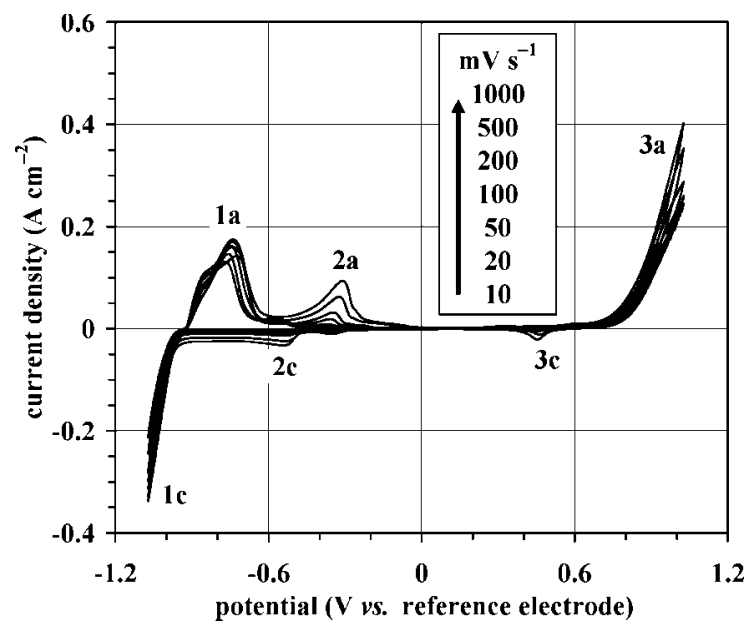

Fig. 6. Cyclic voltammograms in molten pure $\mathrm{Li}_{2} \mathrm{MoO}_{4}-\mathrm{Na}_{2} \mathrm{MoO}_{4}$ eutectic at $550{ }^{\circ} \mathrm{C} .1 \mathrm{c}, 2 \mathrm{c}$, and $3 \mathrm{c}$ : reductive reactions. $1 \mathrm{a}, 2 \mathrm{a}$, and $3 \mathrm{a}$ : oxidizing reactions. 


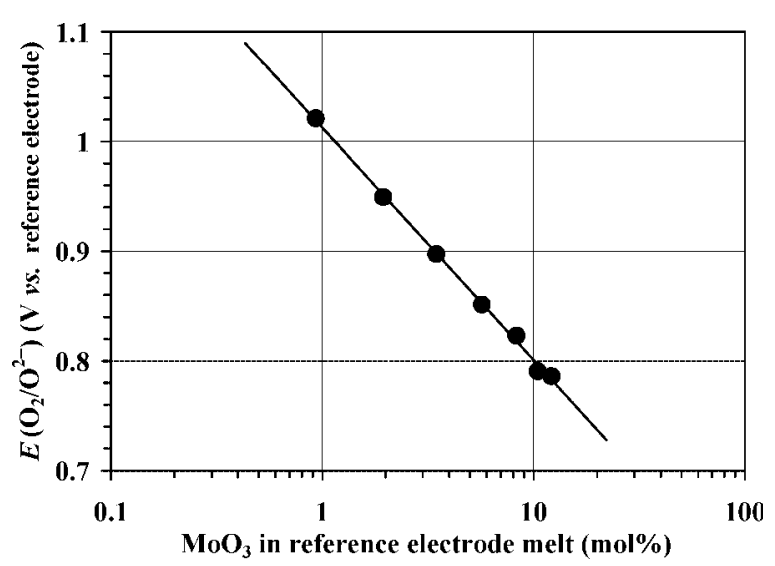

Fig. 7. Influence of the oxygen overvoltage of $E\left(\mathrm{O}_{2} / \mathrm{O}^{2-}\right)$ in molten $\mathrm{Li}_{2} \mathrm{MoO}_{4}-\mathrm{Na}_{2} \mathrm{MoO}_{4}$ eutectic at $550{ }^{\circ} \mathrm{C}$ with $\mathrm{MoO}_{3}$ concentration in reference electrode melt.

To confirm the validity of the reference electrode potential at the electrochemical measurement, the cyclic voltammograms were measured on the condition of 0.93 to $12.17 \mathrm{~mol}_{\%} \mathrm{MoO}_{3}$ in the reference electrode salt. Fig. 7 shows the relation of the $\mathrm{MoO}_{3}$ concentration in the reference electrode salt to the oxygen overvoltage, $E\left(\mathrm{O}_{2} / \mathrm{O}^{2-}\right)$, in molten pure $\mathrm{Li}_{2} \mathrm{MoO}_{4}-\mathrm{Na}_{2} \mathrm{MoO}_{4}$ eutectic at $550{ }^{\circ} \mathrm{C}$. This $E\left(\mathrm{O}_{2} / \mathrm{O}^{2-}\right)$ was defined as the potential that the tangent of the oxygen generating reaction 3a in Fig. 6 was intersected with current density of $0 \mathrm{~A} \mathrm{~cm}^{-2}$. The relation of $E\left(\mathrm{O}_{2} / \mathrm{O}^{2-}\right)$ to the logarithm of $\mathrm{MoO}_{3}$ concentration in reference elctrode salt has a good linearlity as shown in Fig. 7, but the redox reaction in the reference electrode could not be clarified accurately in this study. The slope of this line in Fig. 7 is equivalent to 0.75 electron exchange reactions when calculating from the Nernst's relation.

To confirm the stability of the reference electrode potential with $12.17 \mathrm{~mol}_{\%} \mathrm{MoO}_{3}$ in the electrode used in this study, the cyclic voltammograms were measured repeatedly for $150 \mathrm{~min}$. The cyclic voltammogram after $150 \mathrm{~min}$ corresponded to the initial result, and the stability of the cyclic voltammetry was confirmed.

Fig. 8 shows the cyclic voltammograms of dissolved uranium species in molten $\mathrm{Li}_{2} \mathrm{MoO}_{4}-\mathrm{Na}_{2} \mathrm{MoO}_{4}$ eutectic at $550{ }^{\circ} \mathrm{C}$ for various measuring potential ranges. The $\mathrm{UO}_{2}$ concentration of the melt was $1.02 \mathrm{~mol} \%$. The reductive reactions of dissolved uranium species in the melt were observed in a potential range that was more negative than $-0.1 \mathrm{~V}$ ( $v s$. reference electrode) as shown Ic, IIc and IIIc in Fig. 8, and the oxidizing reactions were observed in Ia, IIa, IIIa, and IIIa' in Fig. 8.

The reductive reaction of Ic and oxidizing reaction of Ia are presumed to be the redox reaction of the $\mathrm{UO}_{2}{ }^{2+} / \mathrm{UO}_{2}{ }^{+}$ couple, because the existence of the uranyl ions, $\mathrm{UO}_{2}{ }^{+}$and $\mathrm{UO}_{2}{ }^{2+}$, was confirmed by the above-mentioned absorption spectrophotometry. To confirm that this redox reaction is a soluble-soluble reaction, cyclic voltammograms in potential range of -0.25 to $0.4 \mathrm{~V}$ were measured for various potential sweep rates ranging from 5 to $500 \mathrm{mVs}^{-1}$, as shown in Fig. 9. The reductive current of reaction Ic included other reactions, but the current density of this redox couple increased with an increase of the potential sweep rate. As for oxidizing reaction of Ia, the relation between the square root

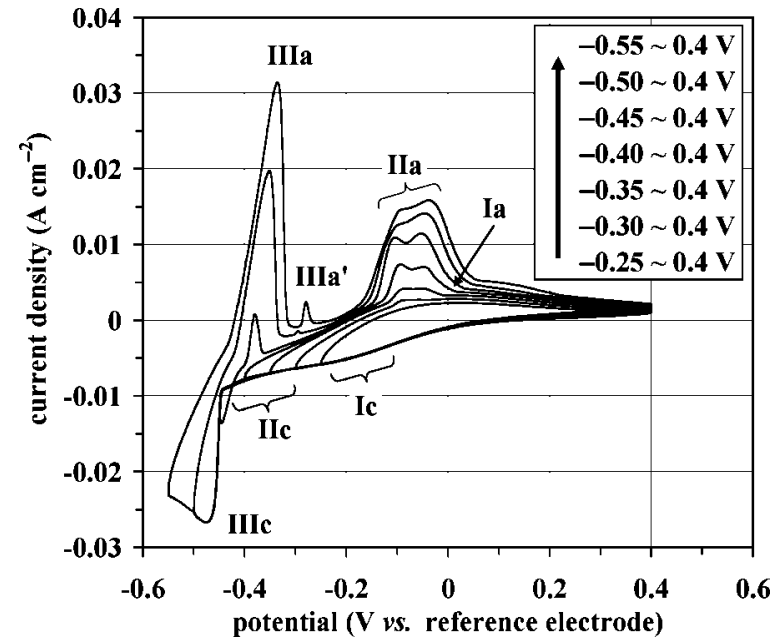

Fig. 8. Cyclic voltammograms of dissolved uranium species in molten $\mathrm{Li}_{2} \mathrm{MoO}_{4}-\mathrm{Na}_{2} \mathrm{MoO}_{4}$ eutectic at $550^{\circ} \mathrm{C}$ for various measuring potential ranges. $\mathrm{UO}_{2}$ concentration in the melt was $1.02 \mathrm{~mol} \%$. Potential sweep rate: $10 \mathrm{mV} \mathrm{s}^{-1}$. Ic, IIc, and IIIc: reductive reactions. Ia, IIa, IIIa, and IIIa': oxidizing reactions.

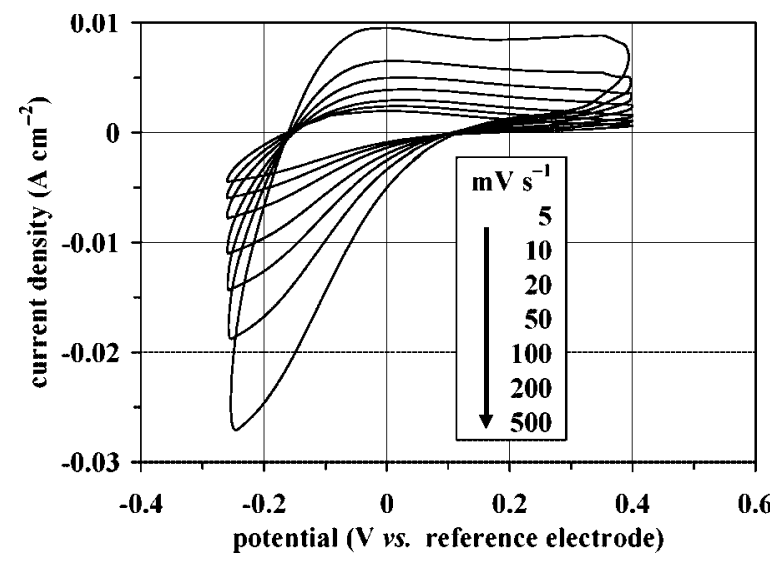

Fig. 9. Cyclic voltammograms of dissolved uranium species in molten $\mathrm{Li}_{2} \mathrm{MoO}_{4}-\mathrm{Na}_{2} \mathrm{MoO}_{4}$ eutectic at $550^{\circ} \mathrm{C}$ for various potential sweep rates. $\mathrm{UO}_{2}$ concentration in the melt was $1.02 \mathrm{~mol} \%$.

of potential sweep rate and the oxidizing current density showed a good linearity.

The deposition current peak of dissolved uranium species in the melt was observed in a potential range that was more negative than $-0.45 \mathrm{~V}$ shown as IIIc in Fig. 8, and the dissolution current peak of deposited uranium compounds on the working electrode was observed below -0.3 to $-0.4 \mathrm{~V}$ shown as IIIa and IIIa' in Fig. 8. And reductive reaction of IIc below -0.4 to $-0.3 \mathrm{~V}$ and oxidizing reaction of IIa over -0.15 to $0 \mathrm{~V}$ accounted for deposition of other uranium species and dissolution of uranium compounds. Since these deposit samples by reactions of IIc and IIIc were so small, they were not identified by the XRD analysis.

However, the deposition potential of uranium compounds as shown IIIc in Fig. 8 is close to the potential that was deposited molybdate compounds shown as 2c in Fig. 6. Therefore, it was suggested that the uranium species in this molten $\mathrm{Li}_{2} \mathrm{MoO}_{4}-\mathrm{Na}_{2} \mathrm{MoO}_{4}$ eutectic are recovered as mixed uranium-molybdenum oxides by electrolysis. In following investigations, several grams of the compound could be collected and identified the phase. 


\section{Conclusion}

In this study, the absorption spectrophotometry and cyclic voltammetry of dissolved uranium species in the molten lithium molybdate-sodium molybdate eutectic at $550{ }^{\circ} \mathrm{C}$ were carried out. This melt is the binary alkaline molybdate mixture with the lowest melting point, and the corrosion damage of the quartz cell could be avoided in these measurements.

As the results of spectrophotometry, it was found that the major ions of uranium species dissolved in the melt were uranyl penta-valent ions of $\mathrm{UO}_{2}{ }^{+}$, whose observed absorption spectra were similar to those of $\mathrm{UO}_{2}{ }^{+}$in molten chlorides. After purging dry oxygen gas into the melt, the absorption peaks of $\mathrm{UO}_{2}{ }^{+}$decreased and $\mathrm{UO}_{2}{ }^{+}$was oxidized to the uranyl hexa-valent ion of $\mathrm{UO}_{2}{ }^{2+}$.

In the cyclic voltammetry, it was found that the potential width of electrochemical window in the melt was narrower than that in the molten chlorides. When $\mathrm{UO}_{2}$ was dissolved into the melt, the reductive reaction of the uranium species was observed. It was suggested that the uranium species in the melt are recovered as mixed uranium-molybdenum oxides by electrolysis, since the reduction potential of uranium species is close to the deposition potential of the molybdenum oxide compounds.

Acknowledgment. The authors are grateful to Mr. Kotaro Kikuchi and Mr. Yoshiharu Kano of Nuclear Technology and Engineering Co. Ltd. for the thermal analysis of $\mathrm{Li}_{2} \mathrm{MoO}_{4}-\mathrm{Na}_{2} \mathrm{MoO}_{4}$ mixtures. We thank Mr. Roy Jacobus for his help in improving the English expressions of this paper.

\section{References}

1. Mizuguchi, K., Yasuike, Y., Fukushima, M., Myochin, M.: Pyrochemical reprocessing using molybdate melt chemical and electrochemical behaviors of uranium oxides in $\mathrm{Na}_{2} \mathrm{MoO}_{4}$ melt. Trans. At. Energy Soc. Jpn. 6, 484 (2007) [in Japanese].

2. Miyake, C., Matsumura, M., Taniguchi, K.: Mutual oxidation states of uranium and molybdenum in U-Mo-O ternary oxides. J. Less-Common Metals 163, 133 (1990).

3. Hoermann, F.: Contribute to the knowledge of molybdates and tungstates. Z. Anorg. Allg. Chem. 177, 145 (1928) [in German].

4. Nagai, T., Fujii, T., Shirai, O., Yamana, H.: Study on redox equilibrium of $\mathrm{UO}_{2}{ }^{2+} / \mathrm{UO}_{2}{ }^{+}$in molten $\mathrm{NaCl}-2 \mathrm{CsCl}$ by UV-Vis Spectrophotometry. J. Nucl. Sci. Technol. 41, 690 (2004).

5. Smolenskii, V. V., Bove, A. V., Mityaev, V. S., Komarov, V. E.: Cathodic reactions in electrolysis of an $\mathrm{Na}_{2} \mathrm{MoO}_{4}-\mathrm{UO}_{2} \mathrm{MoO}_{4}$ melt. Radiokhimiya. 37, 336 (1995) [in Russian].

6. Coope, P. J., Thisltlethwaite, W. P.: The Absorption spectra of acidified molybdate solutions. J. Inorg. Nucl. Chem. 2, 125 (1956).

7. Adams, M. D., Wenz, D. A., Steunenberg, R. K.: Observation of a uranium(V) species in molten chloride salt solutions. J. Phys. Chem. 67, 1939 (1963).

8. Khokhryakov, A. A.: Electronic absorption spectra of uranylcontaining molten halides. Radiokhimiya 40, 400 (1998) [in Russian].

9. Carrell, M. A., Wilder, D. R.: Visible and near-infrared absorption of uranium in sodium-silicate glass. J. Nucl. Mater. 13, 142 (1964).

10. Gruen, D. M., McBeth, R. L.: Oxidation states and complex ions of uranium in fused chlorides and nitrates. J. Inorg. Nucl. Chem. 9, 290 (1959).

11. Polovov, I. B., Volkovich, V. A., Charnock, J. M., Kraj, B., Lewin, R. G., Kinoshita, H., May, I., Sharrad, C. A.: In situ spectroscopy and spectroelectrochemistry of uranium in high-temperature alkali chloride molten salts. Inorg. Chem. 47, 7474 (2008).

12. Gossink, R. G., Stevels, J. M.: Density and surface tension of molten alkali molybdates and tungstates in connection with structure and glass formation. J. Non-Cryst. Solids 5, 217 (1971). 